\title{
Most or Almost All of the Time
}

National Cancer Institute

\section{Source}

National Cancer Institute. Most or Almost All of the Time. NCI Thesaurus. Code C125892.

An indication that something happens or happened most or almost most of the time. 